\title{
Odor space as receptor space
}

\author{
Sigrun Korsching \\ From 1st International Workshop on Odor Spaces \\ Hannover, Germany. 4-7 September 2013
}

Many attempts are being made to categorize odors according to physicochemical properties or hedonic value and valuable insights have been obtained correlating the former with the latter. However, both properties may be argued to be peripheral to the basic definition of an odorous compound. The ability of a compound to activate an olfactory receptor makes an odor out of that compound. Thus, in a very basic sense, the olfactory receptors present in a species span the odor space that may be perceived by that species. The meaning of an odor, on the other hand, is a highly derived property that depends on the ecological requirements of the respective species, and indeed the same odor may carry very different and even opposing meaning for different species. Physicochemical properties may allow a compound to be an odor in some species, but not in others (e.g. amino acids), but again this is mediated by the presence of the appropriate receptors. Thus a thorough knowledge of olfactory receptor space would seem to be required to fully understand odor space. The increased availability of genome sequences of many different species has allowed to identify (nearly) complete chemosensory receptor families to an extent that was difficult to imagine not so long ago. We have performed phylogenetic analyses to delineate chemosensory receptor repertoires of several lower vertebrates, and find that evolutionary dynamics are characteristically different between different olfactory receptor gene families, and within a gene family between ray-finned and lobe-finned vertebrates. A particular striking example is the V1R family, which is a large, highly dynamic and rapidly evolving family in mammals and other tetrapods, but a small family with a stable gene number in teleosts.

Published: 16 April 2014

Institute of Genetics, University of Cologne, Cologne, Germany
doi:10.1186/2044-7248-3-S1-04

Cite this article as: Korsching: Odor space as receptor space. Flavour

2014 3(Suppl 1):04.
Submit your next manuscript to BioMed Central and take full advantage of:

- Convenient online submission

- Thorough peer review

- No space constraints or color figure charges

- Immediate publication on acceptance

- Inclusion in PubMed, CAS, Scopus and Google Scholar

- Research which is freely available for redistribution
( Biomed Central 